Jo Spaans

\title{
PARAGONS OF PIETY: REPRESENTATIONS OF PRIESTHOOD IN THE LIVES OF THE HAARLEM VIRGINS
}

(The Pastor Bonus [Papers read at the British-Dutch Colloquium at Utrecht, 18-21

September 2002] Dutch Review of Church History 83 (2003), 235-246)

\section{Introduction}

In 1582, a year after the Estates of Holland had proscribed all forms of Catholic organisation and all exercise of the Catholic religion, a Haarlem priest, Nicholas Wiggerts Cousebant, recruited two young women to be the first members of a new type of religious community. Others soon followed. The sisters were to live an ascetic life, modelled on the Poor Clares, but without the amenities of an endowed convent, and to devote their lives to prayer for the restoration of the Church. They were underfed and miserably housed, in small back rooms and cramped attics, and had to trek back and forth to the house-church of Wiggerts' father for their strenuous rounds of prayers, day and night. Although they were young and full of zeal, the ardours of this life took their toll, and mortality among the sisters was alarmingly high.

Cousebant, son of a wealthy Haarlem brewer, appears to have been a forceful priest. He was a pillar of the Holland Mission, director of its seminary in Cologne which was to train the desperately needed priests for the preservation of Catholic communities under Protestant rule. The community of virgins was somewhat of a pet project of his. Yet Vicar Apostolic Sasbout Vosmeer nudged him out - partly because of the physical rigours he imposed on the sisters, but mainly because he allowed and even stimulated unchecked flights of mysticism in some of them. Because Cousebant was well-connected and had done eminent service to the Mission this had to be done with infinite circumspection. It took ten years, from 1592 to 1602, before another priest could be put fully in charge of the Haarlem community. Vosmeer appointed Cornelis Arentz, who had been Cousebant's assistant at the Cologne seminary, and who in the preceding years had often taken care of Cousebant's spiritial daughters in his frequent absences, to Cologne or on missionary expeditions in the Republic. ${ }^{1}$ Arentsz's views on asceticism were less extreme. In this, as in other matters, he seems to have taken a measure of guidance from his charges, some of whom were level-headed, practical women, with a knack for organisation. He literally nursed the community back to a healthier form of semi-religious life. ${ }^{2}$

\footnotetext{
${ }^{1}$ E.E.A.J.M. Theissing, Over klopjes en kwezels, Utrecht/Nijmegen 1935, pp. 39-42, 171-174.

${ }^{2}$ On the specific form of semi-religious life of the community, Joke Spaans, 'Time for prayer and time for work. Rule and practice among Catholic lay sisters in the Dutch Republic', in: R.N. Swanson, ed., The Use and Abuse of Time in Christian History, Woodbridge 2002, pp. 161-172.
} 
When he died in 1613, the community changed into the capable hands of Joost Cats, the youngest son of a former official for the King of Spain whose family had suffered financial ruin and exile during the Revolt. He was, even more than Cousebant before him, an important man in the organisation of the Holland Mission. He had been handpicked and trained by Albertus Eggius, vicar-general of the chapter of the vacant see of Haarlem - a body officially suspended by the Estates of Holland and deeply suspected by Rome, but for all practical purposes the backbone of Catholic organisation in Holland, Zeeland and Friesland, under the nominal supervision of the Vicars Apostolic. ${ }^{3}$ When still in his thirties he was balloted into the chapter. He was appointed parish priest of Haarlem, a function revived by Rovenius during the Twelve Years Truce, and in time became Dean of the chapter and archpriest of Amsterdam. He was an able administrator, and under his direction the community flourished. ${ }^{4}$ Upon his death in 1641 he was succeeded by his nephew Boudewijn Cats, also a member of the Haarlem chapter, in time its vicar-general and in 1662 appointed by the Pope Vicar Apostolic for the Holland Mission. ${ }^{5}$

Of these four priests mentioned, Cornelis Arentsz and Joost Cats are portrayed in a remarkable collection of obituaries, the Levens der Maechden (Lives of the Virgins), composed by Catharina (Trijn) Jans Oly, member of the Haarlem community of virgins. The three fat quarto volumes she wrote, contain almost 250 Lives, and also the funeral sermons for most of the virgins dying from the $1620 \mathrm{~s} .{ }^{6}$ Arentsz has only a short obituary here, a longer Life being lost, ${ }^{7}$ for Cats the collection contains both a lengthy obituary and the sermons preached by several priests on his funeral and anniversary. Besides, the Lives of the sisters of course regularly refer to the relationship between the deceased and her father-confessor, as they also contain fairly numerous references to other priests that had played a role in their lives. This allows us to view these priests in the Holland Mission through the eyes of Trijn Jans and her sisters - whose collective memory she must have used. The Lives were read in the community. They show signs of editing, and perhaps they were to some extent censored by the spiritual director. Even so, they reflect ideal and practice of pastoral care in the first half of the seventeenth century from the perspective of religious virgins and other lay persons. The Holland Mission is a seriously understudied area, and most of what we know is culled from normative sources. The Lives of these two father-superiors and their spiritual daughters may add some new perspectives.

\footnotetext{
${ }^{3}$ A. Th Mous, 'Geschiedenis van het voormalig kapittel van de kathedrale kerk van St.-Bavo te Haarlem 1561-1616', Archief voor de geschiedenis van de katholieke kerk in Nederland 4 (1962) 75 184, 295-336, 6 (19640 257-290, 8 (1968) 257-286, 11 (1969) 276-317.

${ }^{4}$ Nieuw Nederlandsch Biografisch Woordenboek (=NNBW), 10 vols, Leiden 1911-1937, VII, 286-287, L.J. Rogier, Geschiedenis van het katholicisme in Noord-Nederland in de 16e en 17e eeuw, 2 vols, Amsterdam 1947², II, 361.

${ }^{5}$ Rogier, Geschiedenis, II, 178-180, NNBW, IV, 405-407.

${ }^{6}$ Trijn Oly, Levens der Maechden, 3 vols, Museum Catharijneconvent Utrecht, Collection Warmond, 92B13-14, 92C10.
}

\footnotetext{
${ }^{7}$ A longer biography is mentioned as part of the collection, but has not (yet) been found, Levens der Maechden I, f. 49r-v.
} 


\section{Cornelis Arentsz}

Unlike the other father-confessors, Cornelis Arentsz is said to have been 'too weak' for other priestly functions, and to have devoted his time to the direction of the community exclusively. This weakness was perhaps age, as he seems to have been involved in pastoral work earlier in life. About his biography, however, practically nothing is known. He was from Amsterdam, and obviously from a devoutly Catholic family, counting at least one other priest and several semi-religious women among its members. Although he did have a family name, Ligthert, he is always referred to by patronym. ${ }^{8}$ The Lives describe him as a deeply pious man, who discouraged unchecked mystical aspirations in his spiritual daughters, and instead taught them a strictly regulated religious life of prayer and meditation, regular attendance at Mass, and useful manual work according to their social status. This form of discipline was laid down in the written Rule and Ordinance he gave his daughters to observe, marking a departure from the approach taken by Cousebant. True holiness was not to be attained through steep flights of mysticism or abuse of the body or of one's health, like rigourous fasting or the use of the discipline. The discipline was even condemned, both by the Catholic ecclesiastical and the Dutch secular authorities, as a breach of propriety. ${ }^{9}$ Purging all willfulness and attachments to worldly matters through obedience, patience, humility, love of God and the neighbour and frequent scrutiny of one's conscience, would slowly but surely, lead one to the sweetness of experiencing the divine. ${ }^{10}$

Arentsz is presented as a living example of his teaching. He consumed his strength in ardent prayer and unflagging patience as well as the toil involved in his successful reorganisation of the community, and his constant care over the sisters. Dispensing the sacraments was of course part of the latter, but even greater importance is given to his preaching, through which he fed the sisters with the Word of God and the teachings of the Fathers. ${ }^{11}$ He preached for the community on Sundays and holy days, sometimes daily, as in the week preceding the feast of St. Bavo, patron saint of Haarlem, to whom he was particularly devoted. Not only did he preach on the home turf of the community, but, like many priests of the Holland Mission, also in the homes of pious Catholics, in Haarlem and in the surrounding villages. At first regular preaching was out of the question, as the penal laws against Catholics, proscribing gatherings of the faithful for religious exercises, were often enforced, however arbitrarily. The stauncher and more spaciously-housed Catholics invited priests to preach in their houses, for their households and a wider audience of carefully selected

\footnotetext{
${ }^{8}$ J.J. Graaff, 'De "vergaderinghe der maechden van den Hoeck" te Haarlem, Bijdragen voor de geschiedenis van het bisdom Haarlem (=BBH) 29 (1905), pp. 145, 289-290

${ }^{9}$ Joke Spaans, Haarlem na de Reformatie: stedelijke cultuur en kerkelijk leven, 1577-1620 ('sGravenhage, 1989), p. 80, Gerrit vanden Bosch, 'Pionnen op een schaakbord? De rol van klopjes in de belangenstrijd tussen jezuïeten en seculiere priesters in de Republiek omstreeks 1606-1610', Trajecta 9 (2000), pp. 266, 279.

${ }^{10}$ Rule and Ordinance, Museum Catharijneconvent Utrecht, Library of the parish of St. Joseph, Ms. 102; cf. F.J.M. Hoppenbrouwers, Oefening in volmaaktheid. De zeventiende-eeuwse rooms-katholieke spiritualiteit in de Republiek (Den Haag 1996), pp. 22-24.

${ }^{11}$ On the popularity of sermons cf. Hoppenbrouwers, Oefening in volmaaktheid, pp. 47-48.
} 
guests. Sermons are presented in the Lives as a particularly effective way to touch the hearts of the audience, edifying the pious, strengthening those wavering in the faith, converting those lapsed into heresy. Many of the virgins were won for the religious life through these sermons. ${ }^{12}$

On the whole Arentsz was loved and revered as a father of a saintly but also somewhat doting character, rather than as a figure of authority. His saintliness inspired his spiritual daughters to obedience of the rule, but in the day to day management of the community he easily deferred to their practical acumen. This somewhat homely familiarity between priest and spiritual daughter came naturally under the circumstances. Like most priests in the Holland Mission Arentsz depended on lay families, and notably on their female members. ${ }^{13}$ Deprived, not only of regular churches, but also of rectories, priests often had to live with their own families or stay with families or virgins who supported the Mission. If they had a place of their own they usually had one or more virgins as housekeepers. This situation exposed them to suspicions and Arentsz got his share of these. During the years 1608-1610 he, among a number of priests in Utrecht and Haarlem, was reported to Rome for objectionable relations with his spiritual daughters. The Lives discreetly mention these troubles, which appear to have been inspired by the rivalry between Jesuits and secular priests in the Mission, but throughout emphasize Arentsz's love for virginal chastity and his personal holiness. ${ }^{14}$

In 1592 he received a vision of Mary and Saint Bernard, patron saints of the community and prime exponents of the virginal state. Saint Bernard in particular had commended to him chastity of the body, charity of the heart and clarity of mind. Paintings of this vision, accompanied with some suitable lines of verse in the vernacular, were made after his death and treasured by members of the community. Years after his death upon inspection it appeared that his body had not decomposed, but was as fresh and firm as it had been in life, a sign taken by the sisters and the Haarlem Catholics in general that he indeed had been a holy man. ${ }^{15}$ Arentsz represents on the whole more a monastic than a pastoral ideal.

\section{Joost Cats}

Arentsz' successor, Joost Cats, was a somewhat more reserved figure, living in more settled times, and occupied with pastoral and other ecclesiastical duties on top of his directorship of the community of virgins. The Life written by Trijn Jansdr Oly ascribes to him a combination of monastic and pastoral virtues. Like Arentsz before

\footnotetext{
${ }^{12}$ This is almost a topos, and several priests are mentioned as preaching in this way in the homes of Catholic families, among them Cousebant, Arentsz, Joost Cats and Albertus Eggius, the vicar general of the chapter.

${ }^{13}$ Note the parallel with the situation in England: John Bossy, The English Catholic Community 15701850, London 1975, p. 153-160.

${ }^{14}$ Vanden Bosch, 'Pionnen op een schaakbord?', pp. 252-283.

${ }^{15}$ Graaff. 'De "vergaderinghe der maechden van den Hoeck", BBH 29 (1905), pp. 295-296, 299-302. The remains of holy virgins were also venerated, Life of Trijn Alberts, Levens der Maechden I, f. 132v146r, f. 146r.
} 
him he dearly loved the community, and he made it his home. As a pastor and administrator he had to travel, but he always hurried home as soon as he was done, in order to be with his spiritual daughters. And although he was only thirty-two when he assumed his duties as superior of a community of virgins, he was said never even to have felt temptations to his chastity. ${ }^{16}$

The representation of Cats's pastoral activities reflects the ideal current in the early Holland Mission. The first requisite for a priest was obedience towards his superiors, expressed, of course, in orthodox teaching and impeccable conduct, but also in the unquestioning following of orders - as only those who know how to obey were considered fit to rule. This fitness for rule was vitally important to the laity, as at the Last Judgement the priest was held to be accountable for the state of the souls of those whose confessions he regularly heard. ${ }^{17}$ Trijn Oly demonstrated Cats's obedience through portraying him as both a dutiful son to his widowed mother, a diligent student who followed the directions of his teachers, and completely loyal to his Church. ${ }^{18}$ Not all priests of the Mission lived up to this standard, and although the Lives are predominantly tuned to the praise of religious virtue, in priests as well as in the Haarlem virgins, they remain not entirely silent on failures in this respect. The unwillingness of Cousebant to yield to the Vicar Apostolic and give up his misguided direction over the Haarlem virgins is, implicitly, presented as a blemish on his reputation, even though his accomplishments as the initiator of the community, ardent missionary and eventually devoted monk and founder of a convent of Franciscan tertiaries in Cologne are recognized throughout.

Obedience could be a problematic issue for Catholics in the Dutch Republic, and the Lives implicitly acknowledge this. Cornelius Hagius, the brother of one of the Haarlem virgins, became ensnared in a three-way conflict of loyalties between two clerical parties and his mother, and was eventually deposed by Vosmeer. Hagius obviously was not an easy character to begin with, but the problems mainly originated in jurisdictional tangles resulting from the collapse of normal ecclesiastical structures. The Life of his sister mentions the grief the insubordination of her brother caused her. ${ }^{19}$ Other cases reflect the problems between seculars and regulars that long plagued the Mission. The town of Hoorn was served by a secular priest who lived in Amsterdam, but served the relatively numerous Catholics in a large region of NorthHolland on regular round-trips. Part of his flock preferred a resident priest, and petitioned the Vicar Apostolic for a regular. The request was denied, but influential lay families invited first a Capuchin, later a Dominican, nonetheless. This led to unrest and unchristian animosity in the local community, which in the Lives is blamed in the first place on the lay persons who, in their commendable religious zeal, had defied the Vicar Apostolic — and who eventually got their just deserts in the form of

\footnotetext{
${ }^{16}$ Life of Joost Cats, Levens der Maechden II, f. 5v.

${ }^{17}$ Van den Bosch, 'Pionnen op een schaakbord?', p. 265.

${ }^{18}$ Life of Joost Cats, Levens der Maechden II, fol. 1r-34r, f. 2r-3r

${ }^{19}$ Joke Spaans, 'Cornelius Hagius, een katholiek priester in een protestantse Republiek', De Zeventiende Eeuw 10 (1994) 29-35, Life of Dieuwer Jans, Levens der Maechden I, f. 54r-56r, f. 34v.
} 
a parish priest who caused an (unnamed) scandal. Implicitly the regulars are considered in contempt as well. ${ }^{20}$

Besides obedience the conduct of the priest required a certain aloofness from worldly pleasures and ambitions. Cats appears to have observed this in an exceptional degree, almost resembling a recluse. His obituary describes how, after completing his studies, he was asked whether he preferred to work in a town or in the countryside - a very unlikely question as Vosmeer had the utmost difficulty in providing pastors outside the larger towns, where priests could live in greater comfort and perhaps also with less exposure. Cats, however, chose to be assigned somewhere in the countryside, where he could live shielded from temptation, secluded among the simple peasants. After he was called to Haarlem and appointed parish priest and canon, functions which entailed social obligations, he would avoid dining with lay persons as much as possible, but if he had to, would exercise moderation in food and drink, and always leave the table at midnight. Considering the current Dutch culture of companiable eating and drinking, which kept people at the table far into the small hours, this was asceticism indeed. If he had to travel back home together with others of the company, he would withdraw into some corner reading or praying, until they were finally done. Under no circumstance would he neglect the celebration of Mass, preaching or hearing confession the next day, because of coming home late after such an evening out. $^{21}$

As well as ascetic detachment, he chose unflagging diligence and incessant labour over comfort. Hearing confession, and preaching are mentioned as especially exhausting work. It must have taken a lot of his time. The community of virgins may well have counted between a hundred and two hundred members, whose Rule and Ordinances prescribed regular examination of conscience and frequent communion, and as parish priest he must also have been responsible for Catholics outside the community. Once Trijn Oly even mentions his disgust with this task, without apparently intending the slightest reproach. ${ }^{22}$ Other priests also experienced the demands of parishioners for confession as a heavy weight. The Life of Weyntje Heyndriks who was housekeeper to the priest Jan Boggen, vice-curate in Haarlem, describes how people came to his door daily for counsel and confession and how at night she shielded him from all but the truly urgent requests for deathbed-confessions to protect his sleep. ${ }^{23}$

Regular confession seems to have fostered close, confidential relations between priests and lay persons. Even Vosmeer himself is presented in the Lives, not so much as the manager of the remnants of the pre-Reformation Church organisation, the arbiter between seculars and regulars or the defender of Dutch Catholic interests before the Holy See, but rather as the personal counsellor in religious affairs to,

\footnotetext{
${ }^{20}$ Life of Giert Heindriks, Levens der Maechden II, f. 248v-259r, f. 255v-257r, J.C. van der Loos, Geschiedenis der voormalige St. Catharinakerk te Amsterdam (Haarlem 1935), pp. 22-26.

${ }^{21}$ Life of Joost Cats, Levens der Maechden II, f. 4v, 6r.

${ }^{22}$ Life of Joost Cats. Levens der Maechden II, f. 17 r-v, f 26v, f. 34 r-v.

${ }^{23}$ Life of Weyntgen Heyndriks, Levens der Maechden II, f. 319r-328v, f. 321r.
} 
mainly wealthy, Catholic families. The parents of Lidwina Dirks Boggen, of impeccably patrician stock, the father a Haarlem burgomaster before the Revolt, had resolved to preserve their virginity in marriage to live a religious life together. The Vicar Apostolic personally persuaded them to enter normal marriage relations, and helped them realise a quasi-monastic lifestyle later on, arranging for them to live, as a couple of recluses, among the Haarlem community of virgins.$^{24}$ Despite his tenuous position and his manifold occupations he thus appears to have been very easily accessible, somewhat of a family friend, to the Catholic social elite. Similar stories could be told about other priests in the early stages of the Holland Mission. Over time, when staties or rectories gave the clergy somewhat greater independence from lay support, relations may have grown less personal.

Contrary to what might be expected, Cats and other priests put a lot of effort into preaching sermons. In Cats's time Catholic places of worship, discreetly hiding behind the facades of ordinary houses and warehouses, could be used with the tacit approval of the secular authorities. The virgins also enjoyed the use of such a private church. Cats often preached for them, on Sundays and holy days. His sermons were wellprepared, learned homilies, firmly founded on biblical and patristic authority rather than on scholastic theology, which he learned by heart, and delivered apparently with all the rhetorical flourishes and emphatic gesturing required by contemporary notions of effective public oratory, 'offering up his sweat in the pulpit', in the words of Trijn Oly, sometimes for hours on end, even when in poor health. Occasionally, hearing confessions and preaching led to total exhaustion. ${ }^{25}$ By this time ordinary lay people also had access to frequent sermons, at least in larger towns. In Haarlem vice-curate Jan Boggen preached daily in the morning, and in the afternoon appears to have repeated and explained the main points of the sermon, adducing the relevant biblical texts, ${ }^{26} \mathrm{a}$ form of pious exercise not unlike the catechising classes held by Reformed ministers of the time. That a priest had to celebrate Mass went without saying, but the pastoral duties that are mentioned in the Lives as the most appreciated by the laity, and taking up most of the energy of the clergy, are hearing confession and preaching.

Apart from this pastoral work and his administrative duties Cats also found the time to write. Trijn Jans does not specify what he wrote, but much of it must have been correspondence with other priests and their influential lay supporters. Books of his hand are unknown. He did leave, however, like his predecessors Cousebant and Arentsz, books of sermons, written from memory by his spiritual daughters. ${ }^{27}$ In these sermons his learning becomes apparent. As far as the Lives are concerned, education was taken for granted in a priest, even though not all may have been as learned as Cats, who studied both the arts and theology, and for a spell taught at the seminary in Cologne. Virgins and other lay persons took pride in sending a son or nephew to study

\footnotetext{
${ }^{24}$ Life of Lidwina Boggen, Levens der Maechden I, f. 387r-391r, f. 387v-388r.

${ }^{25}$ Life of Joost Cats, Levens der Maechden II, f. 17 r-v, f. 25v, f. 27r. f. 28 r-v

${ }^{26}$ Life of Weyntgen Heyndriks, Levens der Maechden II, f. 319r-328v, f. 322v

${ }^{27}$ Several volumes in Museum Catharijneconvent, Collection Warmond.
} 
for the priesthood, or to support deserving boys without the necessary means to attend school and university.

Priests are occasionally mentioned in other roles. It was not altogether unusual that sisters experienced doubt and desperation, manifesting itself in the form of madness and demonic possession. These occurrences were deeply disturbing to the community. ${ }^{28}$ In an earlier period priests would have exorcised these women, and the Lives actually mention exorcism a couple of times, but usually as a memory from a distant past. Apparently, exorcism was a sixteenth-century practice, discontinued around the turn of the century. The most spectacular case is the history of demonic temptation of Trijn Alberts, and her exorcism, locked in iron chains in the choir of the New church of Amsterdam when that was still a Catholic church. ${ }^{29}$ By the seventeenth century prayer for divine assistance, and time, were expected to bring the affected back to sanity.

Catechising is also mentioned rarely. The Lives relate how a priest of Utrecht catechised the young with the help of his sister, a spiritual virgin, and how Cornelis de Jong, priest in The Hague, catechised a patrician adult, converted through the efforts of his Catholic wife, as a preparation for his reconciliation. ${ }^{30}$ This form of religious education, so dear to the Counter-reformation, may not have been very common yet in the early seventeenth century Republic, or perhaps rather the work of schoolmasters and -mistresses than priests.

\section{Conclusions}

The representation of the pastoral ideal in the Lives and the glimpses they afford us of its translation into practice allow us to make a few observations.

First of all: the priests that appear in the Lives are portrayed in an almost exact reverse of the dark picture painted of the pre-reformation clergy. Much of this was of course caricature. Arnoud Jan Bijsterveld has recently argued that on average prereformation priests in the Netherlands were not wholly viri obscuri. At the same time, however, he shows that indeed episcopal control was rather weak, enforcement of ecclesiastical laws and regulations was lax, education was rather general and did not really set priests apart as a class, absenteism and concubinage were socially accepted and therefore widespread, and insubordination not infrequent. ${ }^{31}$ Trijn Oly was very much aware of the difference between old and new clergy. The priests she described were paragons of piety, more specifically Counter-reformation piety, in their obedience to canon law, chastity, diligence and learning.

\footnotetext{
${ }^{28}$ Joke Spaans, 'Violent Dreams, Peaceful Coexistence. On the Absence of Religious Violence in the Dutch Republic', De Zeventiende Eeuw 18 (2002) 149-166, esp. p. 164-166.

${ }^{29}$ Life of Trijn Alberts, Levens der Maechden I, f. 132v-146r, f. 134r-137r.

${ }^{30}$ Both in the Life of Geertruyt van Veen, Levens der Maechden III, 338r-351r, f. 341r, 339r-v.

${ }^{31}$ Cf. A.J.A. Bijsterveld, Laverend tussen kerk en wereld. De pastoors in Noord-Brabant 1400-1570 (Amsterdam 1993), esp. pp. 209-212, 321-368.
} 
One point in the sixteenth-century criticisms, and an important element in the anticlericalism of the time - clerical venality - seems to heve been left out. The Lives are very discreet on the question of money. With the redirection of nearly all ecclesiastical endowments and benefices towards the pious purposes of the new Calvinist regime, the Catholic clergy was in an even more desperate need for donations and payments than the old had ever been. Yet never does the subject of financial obligations of the laity, or the expectation of fees for dispensing the sacraments, come up. Individual lay persons are praised for their generosity towards priests and poor students, for providing room for worship, and ornaments for the churches and vestments, in the same vein as they are praised for their charity towards the poor. Whatever money changed hands, and that may well have been a lot, is presented as purely voluntary giving - the impression of the Catholic community in this period is very markedly that of 'voluntary religion', quite unlike the Counterreformation Catholicism of the South. The dependence on lay patrons may have changed pastoral ideals, both on the supply side (priests) and on the demand side (laity).

A second observation concerns the fusion between monastic and pastoral ideals. The monastic lifestyle of Cornelis Arentsz fitted his function, as he had no real pastoral responsibilities beyond the direction of the community of virgins. But Joost Cats, who had many responsibilities outside the community, also lived as a monk as much as practicable. Counter-reformation efforts at educating the laity are usually described as attempts to 'monasticize' them, to introduce monastic exercises and values into the everyday lives of men and women 'in the world'. The clergy of the early Holland Mission, lacking the social authority that comes with official recognition and the public display of rank, seems to have judged it necessary to provide the laity with living examples of this piety in their own conduct. This, rather than the influence of Protestant austerity, may go a long way towards explaining the modest and withdrawn, almost self-effacing lifestyle often ascribed to the priests of the Northern Provinces in contrast to their more 'baroque' counterparts in the Catholic South. ${ }^{32}$

Thirdly it appears that preaching was a very important part of priestly duties in the early seventeenth century. Both priests and laity valued sermons highly. Sermons were meant not only to be edifying, but above all to be moving. This must have been especially important for Catholics, even more so than for their sermon-addicted Calvinist compatriots, as Counter-reformation Catholic theology stressed the importance of the co-operation of the believer with divine grace. ${ }^{33}$ Sermons had to appeal to the will, the affects and the mind of the hearers, to move them to this cooperation. They could therefore not be the short homilies usually associated with Catholic preaching, but may often have been lengthy and thorough, and delivered according to the popular taste for public oratory. In these formal aspects they may not have differed much from contemporary Protestant sermons. Normative sources on Catholic spirituality emphasize the centrality of the sacraments, but in the Lives the

\footnotetext{
${ }^{32}$ Rogier, Geschiedenis, II, 794-800, Hoppenbrouwers, Oefening in volmaaktheid, pp. 95-98, cf also the passage on the influence of the monastic-priestly ideals in the Imitatio Christi, p. 33.

${ }^{33}$ Hoppenbrouwers, Oefening in volmaaktheid, pp. 9-12, cf. Life of Joost Cats, Levens der Maechden II, f. $1 \mathrm{r}-34 \mathrm{v}, \mathrm{f} .17 \mathrm{r}-\mathrm{v}$
} 
sacraments do not seem much more important than sermons, whose effects they consolidated. This too may have to do with lay demand, a demand less for formal liturgy and more for guidance towards a godly life. 